\title{
The Censorship Phenomenon in College and Research Libraries: An Investigation of the Canadian Prairie Provinces, 1980-1985
}

\author{
Alvin M. Schrader, Margaret Herring, \\ and Catriona de Scossa
}

\begin{abstract}
Although college and research libraries in North America are generally thought to be immune to censorship pressures, no impartial research has been undertaken to date to verify this perception. A five-page questionnaire was mailed to the libraries of 68 postsecondary educational institutions in the three prairie provinces of Canada in order to determine two things: first, the extent of pressures to remove, relocate, or reclassify library materials between 1980 and 1985; and second, to determine the effectiveness of written selection policies in dealing with such pressures. Among the 47 responding libraries, 14 (30 percent) reported that they had experienced some kind of censorship pressure during the six years under study. Almost all of these libraries served student populations under 5,000, but some of the larger institutions also reported challenges of one kind or another.
\end{abstract}

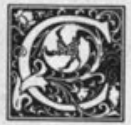

ollege and research libraries are generally thought to be immune to censorship pressures. For example, John Robotham and Gerald Shields (1981) asserted that "the libraries of educational institutions are generally free from public pressure to acquire or reject a particular item. There is, of course, a kind of general pressure on them to adapt to a changing society, but this doesn't apply to any one book or film." 1 The lack of concern with censorship at postsecondary institutions is nowhere better revealed than in Library Literature itself: between 1980 and June 1988, we found only two articles dealing with this topic.

This state of affairs is somewhat under- standable, given the mandate of institutions of higher learning generally. Colleges and universities are perceived as forums for the free exchange of ideas, differing from public schools which are, among other things, agents of socialization. To conduct research and produce legitimate scholarship at the postsecondary level, it is widely recognized that students and faculty alike must have access to all sides of an issue, no matter how controversial the subject matter. Presumably, college and research libraries are included in the intellectual mandate of their parent institutions.

But just how justified is this presumption? Are there no restraints on intellectual freedom, no pressures at all on these

Alvin M. Schrader is Associate Professor, Faculty of Library and Information Studies, University of Alberta, Edmonton, Alberta, Canada T6G 2J4. Margaret Herring is Librarian/Cataloguer for the Calgary Board of Education, Calgary, Alberta, Canada T2G 3CS. Catriona de Scossa is Associate Professor, Faculty of Library and Information Studies, Edmonton, Alberta, Canada T6G 2J4. The authors thank Dr. Dianne Hopkins, Assistant Professor of Library and Information Studies, University of Wisconsin-Madison, for critiquing a draft of this paper. 
libraries to remove materials or to restrict access to them? The literature provides no clues.

\section{METHODOLOGY}

The questionnaire survey reported here is the first known effort to collect impartial empirical evidence about these questions from postsecondary libraries. (Although two or three statewide investigations in the recent past have included academic libraries along with public and school libraries, they did not distinguish the censorial incidents by type of library.) In addition, this study has attempted to provide a more complete and accurate picture of the link between possible censorship pressures and the effectiveness of standard written procedures and selection policies to deal with any such pressures. ${ }^{2}$

This investigation was limited to the libraries of postsecondary institutions situated in the Canadian provinces of Manitoba, Saskatchewan, and Alberta, and covered the six years from 1980 to 1985 . It was designed to elicit specific information regarding each request to remove, relocate, or reclassify materials. The information solicited included the title and format of the material involved; the type of individual initiating the complaint; the reason given by the individual for the complaint; the role of a written selection policy in dealing with the complaint; and the final disposition in each case.

A number of important decisions had to be made at the outset of the research project. The first of these concerned the geographic and time parameters of the survey. College and research libraries in the three prairie provinces of Canada were selected for two reasons: first, a study sample of adequate size would be assured; second, the Canadian prairie provinces constitute a fairly distinct regional entity. Although different in several respects, they share a number of similar characteristics, including cultural history, educational practices, economic and industrial objectives, populist political behavior, and religious movements. The study period, 1980 to 1985 , was chosen in order to be able to produce a comprehensive picture without too much risk of inaccuracy due to destroyed records or unreliable memories.

The second major decision concerned the type of instrument that would be used to gather information. It was decided that a mail questionnaire would be most appropriate for several reasons. First, the geographical scope of the study made faceto-face interviews virtually impossible; the time, travel, and expense that would be involved ruled this choice out immediately. The mail questionnaire, on the other hand, is a relatively quick and inexpensive method for the researcher to gather data. The respondent can answer the questions conveniently and in privacy. Consequently, answers may be more candid than if the respondent were confronted with an interviewer face-to-face.

However, mail questionnaires do not allow the researcher to control the conditions under which the questionnaires are completed or to probe deeply into the respondents' actions and attitudes. Furthermore, mail surveys often suffer from low response rates. These limitations may render the information collected somewhat less reliable. When all aspects were taken into account, it was decided that a questionnaire was still the instrument of choice for this research project.

The survey included all Englishspeaking university libraries, community and technical college libraries, and the libraries of religious, biblical, theological, and seminary postsecondary institutions in the three prairie provinces. At least one of these postsecondary institutions offered a mixed curriculum for both senior high school and college students.

The second volume of the thirty-eighth edition of the American Library Directory (1985) was used to compile the list of libraries to which the questionnaire would be sent. While the Directory classifies each library according to type (university, college, public, special, religious, etc.), some discrepancies were noted. For example, the Southern Alberta Institute of Technology (SAIT) was classified as a college library, while the Northern Alberta Institute of Technology (NAIT) was classified as a special library. Every effort was made to detect these discrepancies, but the pos- 
sibility nonetheless exists that some relevant libraries were missed. This Directory was supplemented by the Directory of Community and Technical College Libraries and Resource Centres in Canada (1983), which included a number of libraries that had been omitted from the American Library Directory. The final list comprised 68 libraries (one other library, initially included, was later found to be a high school library and therefore was omitted from the study figures).

Working from previously published research and research instruments, principally related to public and school libraries, ${ }^{3,4}$ the questionnaire and covering letter for the study were evaluated by two faculty members and two students in the Faculty of Library and Information Studies, University of Alberta. As a result, several major revisions were incorporated into the second draft, which was reviewed again. Only minor modifications were suggested at this stage, and these were incorporated into the third and final version of the questionnaire. Each of the covering letters was personalized with the name of the librarian or information officer in charge as well as the address of the library. A stamped, self-addressed return envelope was provided for each questionnaire.

Questionnaires were mailed at the end of January 1986, with three weeks allowed for returns. There was no follow-up letter because of the project's time constraints and the additional expense that would be incurred.

\section{FINDINGS}

From the initial population of 68 libraries, 47 usable questionnaires were re- ceived. This represents a response rate of 69 percent, relatively high for a mail survey of this type, and indicates widespread interest by prairie postsecondary educational institutions in the issue of censorship. Most of the 44 responding libraries that provided enrollment data served populations of fewer than 5,000 students. The overall median per parent institution was 893 students, with a range from 70 to 23,000 .

\section{"Fourteen of the 47 respondents (30 percent) reported some kind of cen- sorship pressure between 1980 and 1985.'}

Table 1 shows that 14 of the 47 respondents ( 30 percent) reported some kind of censorship pressure between 1980 and 1985. Overall, 79 percent of the affected libraries served institutions with fewer than 5,000 students.

Of these 14 libraries, the majority experienced multiple cases of censorship pressure, ranging as high as five incidents during the six-year period under study. (See table 2.)

All told, these 14 libraries reported 36 instances of censorial pressures. Most of the incidents involved requests to remove library materials. One incident, however, was a case of suggested mutilation-a request that the offending matter be cut out. Another request involved pressure to not purchase material. For a full history of the 36 incidents, see appendix $\mathrm{A}$.

TABLE 1

FREQUENCY OF CENSORSHIP PRESSURES ON POSTSECONDARY LIBRARIES, 1980-1985

\begin{tabular}{|c|c|c|c|c|c|c|}
\hline \multirow[b]{2}{*}{$\begin{array}{c}\text { Number of } \\
\text { Students (FTE) }\end{array}$} & \multicolumn{6}{|c|}{ Libraries } \\
\hline & Number & Percent & Number & Percent & Number & Percent \\
\hline Under 5,000 & 27 & 82 & 11 & 79 & 38 & 81 \\
\hline $5,000-9,999$ & 2 & 6 & - & - & 2 & 4 \\
\hline $10,000-14,999$ & - & - & 1 & - & 1 & 2 \\
\hline $15,000-19,999$ & - & - & 1 & 21 & 1 & 2 \\
\hline $20,000-24,999$ & 1 & 3 & 1 & - & 2 & 4 \\
\hline Unreported & 3 & 9 & $=$ & - & 3 & 7 \\
\hline Total & $\overline{33}$ & $\overline{100}$ & $\overline{14}$ & $\overline{100}$ & $\overline{47}$ & $\overline{100}$ \\
\hline
\end{tabular}


TABLE 2

CENSORSHIP INCIDENTS PER POSTSECONDARY LIBRARY, 1980-1985

\begin{tabular}{lcr}
\hline \hline $\begin{array}{l}\text { Censorship } \\
\text { Incidents } \\
\text { per Library }\end{array}$ & Number & Libraries \\
\hline 1 & 3 & Percent \\
2 & 4 & 21 \\
3 & 4 & 29 \\
4 & 2 & 29 \\
5 & 1 & 14 \\
$\quad$ Total & 14 & $\frac{7}{100}$ \\
\hline
\end{tabular}

Table 3 shows the full range of censorship pressure on postsecondary libraries during the period under study. The majority of the incidents ( 27 of 36 , or 75 percent) occurred in libraries serving fewer than 5,000 students. Nonetheless, it should be stressed that several of the larger institutions also reported challenges. And in statistical terms, this study demonstrates that the larger the student population, the more likely the library will experience censorship pressures. ${ }^{5}$

Respondents indicated that two-thirds of the challenged materials were books; the remainder involved eight periodicals, two films, one encyclopedia, and one videotape.

The content of the challenged material varied widely, from diet, biography, and best-seller fiction to historical revisionism and homosexuality. Two principal types of content could be identified: (1) material that was sexually explicit or dealt with human reproduction and sexual relations; and (2) material that was alleged to be blasphemous, or that dealt with the occult, or that was otherwise in conflict with the religious affiliation of the parent institution.
Sexuality materials constituted the larger of the two major types and included such titles as: The Act of Love, author unknown, The Intimate Marriage by Clive Bell, and Lying in Bed by Mary Howes. Two periodicals were reported: Playboy and Sports Illustrated ("swimsuit edition"). The film, Not a Love Story, and videotapes used in sex therapy courses also fell into this category. The materials in this category were alleged to be offensive, provocative, or exploitive. Many also felt that these works were sexist and degrading to women and that users were not mature enough to deal with them responsibly.

Among the second group of works were such titles as The Far Country by Paul Twitchell, Satanic Bible by Anton S. La Vey, Jonathan Loved David: Homosexuality in Biblical Times, and Wittenberg Door. According to one respondent, the latter is the Christian equivalent of National Lampoon; that is to say, it is a periodical that parodies Christian doctrine and issues. Some of these types of materials were alleged to be dangerous or harmful to readers.

A third group of material, much smaller than the two just discussed, could also be distinguished. This category included materials that were considered to be racist or hate literature. Only two specific titles were reported by respondents: the eleventh edition of the Encyclopaedia Britannica and The Hoax of the Twentieth Century by Arthur R. Butz. A third incident involved a general complaint regarding LC subject headings concerning homosexuality.

Other titles could not be placed readily into one of these categories. They covered a wide range of subjects, including suicide, poaching, dieting, crime, and the Soviet Union.

TABLE 3

TYPES OF CENSORSHIP INCIDENTS BY 1985 STUDENT POPULATION

\begin{tabular}{|c|c|c|c|c|}
\hline Requests to & $\begin{array}{l}<5,000 \\
\text { Students* }\end{array}$ & $\begin{array}{l}>5,000 \\
\text { Studentst }\end{array}$ & No. & $\%$ \\
\hline Remove & 22 & 7 & 29 & 81 \\
\hline Relocate & 5 & - & 5 & 14 \\
\hline Reclassify & $=$ & $\underline{2}$ & $\underline{2}$ & 5 \\
\hline Total & $\overline{27}$ & $\overline{9}$ & $\overline{36}$ & $\overline{100}$ \\
\hline
\end{tabular}

*Libraries serving under 5,000 students.

t Libraries serving 5,000 or more students. 
With regard to the source of complaints, every major academic constituency was represented. Students and members of the teaching staff initiated approximately 40 percent of the complaints, while administrative officials were involved in another 20 percent. More significant is the fact that, in 40 percent of all cases, a member of the library staff initiated or was one among several initiators.

Of the 47 responding libraries, 29 (62 percent) said they had a written selection policy. Many librarians, however, qualified their answers somewhat with additional phrases like "in part," "a general one, prioritizing types of acquisitions," "sort of," "'but it needs updating," and "draft format."

Of these 29 respondents with a written selection policy, only 7 reported that the policy provided a standard written procedure to be followed in the event of requests for removal, relocation, or reclassification of library materials. Moreover, in only 10 cases did the written policy specify the library's position with regard to intellectual freedom.

In spite of the frequent existence of written policies, and in spite of the majority view that a written policy is an effective tool to prevent censorship, respondents reported that the policies were ignored in two-thirds of the complaints received during the period under review in this study. Also noteworthy is the fact that in 3 of the cases reported, a written policy was actually used to expedite censorship rather than to prevent it.

\section{"In approximately 60 percent of the incidents, some kind of censorial action was taken: either removal, re- location, or reclassification in accord- ance with the complaint."}

With regard to the final disposition of the reported complaints, the data are not altogether encouraging. In approximately 60 percent of the incidents, some kind of censorial action was taken: either re- moval, relocation, or reclassification in accordance with the complaint. (In several of these incidents, the material was removed only temporarily and then replaced when the conflict had subsided!) In only 40 percent of the incidents was the challenged material retained on the shelves intact.

Comments by respondents added many further insights into the complexities of the censorship phenomenon in college and research libraries on the Canadian prairies:

The only restriction I can think of in an academic library would be in the case of revisionist literature. The rest are curriculum-based.

One of the most insidious forms of censorship is hidden from the kinds of activities listed in this questionnaire. Many of the books we hold, for example, would not appear in other libraries because of a silent censorship applied to materials with an evangelical Christian perspective. They are just not purchased. Too bad you cannot measure such prejudicial tendencies.

Some distributors place restrictions, for example, a number of criminology items may be viewed only with instructor's permission. We also abide by "restricted adult" ratings as applied by the Alberta Board of Censors.

I have had no requests to remove or reclassify but have had to go through long verbal defenses of some items I have purchased.

Screening and censorship of materials takes place in the selection and buying process. Most materials which are considered inappropriate or objectionable (by library staff or faculty) are screened upon arrival and are not cataloged. (These items are returned, sold, or remain in the librarian's office; the latter items are not considered part of the collection.)

Our selection policy is really quite general in that it states our major collection in the religious field consists of books in the ... tradition but that books with a different persuasion are collected for reference purposes. In [our] incidents, it was understood that the materials removed went beyond reference to persuasion of something in conflict with our persuasion. Thus I would say it was effective in making the decision to remove.

I think as little fuss as possible should be made; the material should simply be removed if it does not agree with the school's principles and standards and beliefs. 
Since a college of our nature would not consider acquiring obscene or pornographic materials, the selection policy is quite adequate to assure that the collection contains only ideas-and we should have no fear of ideas.

Obviously we can live without [a selection policy]. It's handy to have something to point to but that doesn't mean, in my opinion, that you can't ever make exceptions."

[Selection policies] work for library internal processing but are completely ineffective when the administration becomes involved, especially when a donor is involved.

... filling out this questionnaire has made me realize that we'd better revise the section on censorship in our acquisitions policy.

We censored the Sports Illustrated issue on bathing suits because of the environment in the library when the issue was left uncensored. The female staff felt exploited as fellows (mostly high school) used the magazine. We do restrict access to sexual or human reproduction materials because there have been problems with students in these areas who have accessed the material. Now upon request the material is provided but a request must be given-this has controlled the problem earlier identified by the counseling department. By and large we restrict our book selection rather than censor and we make very sure of the grounds for a book if questions could arise. Once acquired we group sexual material separately, otherwise we take a hard line on censoring and argue for direct access in the stacks.

\section{CONCLUSIONS}

This study has revealed that censorship pressure is very much a reality for libraries at the postsecondary educational level. Three of ten respondents reported receiving a request to remove, relocate, or reclassify some kind of library material.

The data regarding the incidents themselves are interesting for a number of reasons. First, censorship attempts were not confined to any particular format: books, periodicals, films, and videotapes were all targets of complaints. Second, the content of the challenged materials varied widely, although distinct categories did emerge. Diet, biography, best-seller fiction, the occult, human reproduction, historical revisionism, homosexuality-all were the object of censorship attempts. This would seem to substantiate the assertion that no material is neutral for everybody: even the most seemingly innocuous work has the potential to offend someone.

With regard to the effectiveness of written selection policies in preventing censorship, the data are not altogether encouraging. Approximately two-thirds of the respondents stated that their library has a written selection policy. Very few of these policies, however, provided standard procedures to deal specifically with a censorship attempt. This would seem to indicate that many of the respondents did not feel that censorship is a serious threat to the intellectual integrity of their collections and that, should such incidents arise, ad hoc measures would be adequate to deal with them.

\section{"In only one of every three incidents was the written policy used to deal with the case. The problem is com- pounded by the frequent participa- tion of librarians and other members of the library staff in censorship at- tempts."}

Moreover, in only one of every three incidents was the written policy used to deal with the case. The problem is compounded by the frequent participation of librarians and other members of the library staff in censorship attempts. Perhaps it is not surprising, therefore, to learn that in almost 60 percent of the incidents, some type of censorial action was taken.

Although this study has revealed that far more censorship attempts have occurred in academic libraries-at least in the Canadian prairie provinces-than was previously assumed, the data regarding the effectiveness of written selection policies in dealing with this censorship are inconclusive. It seems that perceptions held by college and research librarians on the nature of this issue do not necessarily accord with reality. While a majority of them believe that written selection policies would be effective in dealing with censorship, only a minority have actually established such standard procedures. Even 
the existence of a standard procedure does not necessarily give the library an advantage, for, as noted, the procedure might not be used at all in dealing with a censorship attempt or, if used, its purpose might be subverted to expedite censorship rather than to prevent it.

In at least one respect, this project is the first of its kind. To the best of our knowledge, no other comprehensive study has been undertaken of the censorship phenomenon in the libraries of postsecondary educational institutions in either Canada or the United States. Given the broad cultural similarities between the Canadian prairies and the American Midwest, the censorship phenomenon may turn out to be a common pattern that crosses political boundaries.
Although the academic institution in North America is widely perceived as an open forum for the free exchange of ideas, the study reported here demonstrates that this idealistic perception is at least partially inaccurate and illusory. It is hoped that similar studies will be undertaken in the near future in many other geographic areas, nationally and internationally, so that our understanding of the issues is broadened, and so that senior administrative policymakers-and librarians-will be forewarned. Based on the present study, we believe that library censorship is a reality at the postsecondary level everywhere in the democratic world, in spite of hitherto unquestioned assumptions to the contrary.

\section{REFERENCES AND NOTES}

1. John Robotham and Gerald Shields, Freedom of Access to Library Materials (New York: NealSchuman, 1981), p.19.

2. For the full technical report of this project, see Margaret Herring, "The Effectiveness of Written Selection Policies in Preventing Censorship in Academic Libraries in the Prairie Provinces Since 1980 " (M.L.S. research project, University of Alberta, 1986).

3. David Jenkinson, "The Censorship Iceberg: The Results of a Survey of Challenges in School and Public Libraries." School Libraries in Canada 6:19-30 (Fall 1985). Also published in Canadian Library Journal 43:7-21 (Feb. 1986).

4. Keith Walker, "Censorship in Alberta Public Libraries: A Survey of Requests for Removal of Library Materials" (M.L.S. research project, University of Alberta, 1984). Published as "Censorship Iceberg: Results of an Alberta Public Library Survey," by Alvin M. Schrader and Keith Walker, Canadian Library Journal 43:91-95 (Apr. 1986).

5. Statistical analysis of the data reveals a moderately strong relationship between size of student population served by the library and reported number of censorship incidents (Pearson correlation coefficient $=.31$, significance $=.019$, valid cases $=44$ ). 
APPENDIX A

HISTORY OF CENSORSHIP INCIDENTS REPORTED BY COLLEGE AND RESEARCH LIBRARIANS IN THE CANADIAN PRAIRIE PROVINCES, 1980-1985

\begin{tabular}{|c|c|c|c|c|c|c|c|c|c|c|}
\hline $\begin{array}{l}\text { Type of } \\
\text { Material } \\
\end{array}$ & Author & Title & $\begin{array}{l}\text { Type of } \\
\text { Request }\end{array}$ & Complainant & $\begin{array}{l}\text { Reason for } \\
\text { Complaint }\end{array}$ & $\begin{array}{l}\text { Written } \\
\text { Selection } \\
\text { Policy }\end{array}$ & $\begin{array}{l}\begin{array}{l}\text { Procedure } \\
\text { for } \\
\text { Complaints }\end{array} \\
\end{array}$ & $\begin{array}{l}\text { Policy } \\
\text { Used }\end{array}$ & $\begin{array}{l}\text { Method of } \\
\text { Handling } \\
\text { Incident }\end{array}$ & $\begin{array}{c}\text { Final Result } \\
\text { of Complaint }\end{array}$ \\
\hline 1. Book & Dominian, Jack & $\begin{array}{l}\text { Marital Break- } \\
\text { down }\end{array}$ & Relocation & $\begin{array}{l}\text { Administrative } \\
\text { official of } \\
\text { the institu- } \\
\text { tion }\end{array}$ & Censorship & Yes & No & No & Request was acceded to & $\begin{array}{l}\text { Material relocated to library office. } \\
\text { Returned to shelf when complain- } \\
\text { ant left the institution. }\end{array}$ \\
\hline 2. Periodical & & Wittenberg Door & Removal & $\begin{array}{l}\text { Member of } \\
\text { the teach- } \\
\text { ing staff }\end{array}$ & $\begin{array}{l}\text { Blasphemous } \\
\text { material }\end{array}$ & Yes & No & No & Request was acceded to & Subscription cancelled \\
\hline 3. Book & Unknown & $\begin{array}{l}\text { Uncut (a book } \\
\text { about cen- } \\
\text { sorship in } \\
\text { the Cana- } \\
\text { dian film in- } \\
\text { dustry) }\end{array}$ & Removal & $\begin{array}{l}\text { Member of } \\
\text { library } \\
\text { staff }\end{array}$ & $\begin{array}{l}\text { Nudity in } \\
\text { some il- } \\
\text { lustrations }\end{array}$ & No & No & No & $\begin{array}{l}\text { Request was from a } \\
\text { former librarian who } \\
\text { removed the book after } \\
\text { an argument with the } \\
\text { instructor }\end{array}$ & Material removed \\
\hline 4. Book & Davis, Adele & $\begin{array}{l}\text { Let's Eat Right } \\
\text { to Keep Fit }\end{array}$ & Removal & $\begin{array}{l}\text { Community } \\
\text { member }\end{array}$ & $\begin{array}{l}\text { Diet sug- } \\
\text { gested by } \\
\text { author is } \\
\text { dangerous }\end{array}$ & No & No & No & $\begin{array}{l}\text { Reference staff handled } \\
\text { the complaint }\end{array}$ & $\begin{array}{l}\text { Verbal discussion with complainant; } \\
\text { no further action taken }\end{array}$ \\
\hline 5. Books & & $\begin{array}{l}\text { No titles speci- } \\
\text { fied (best- } \\
\text { seller fiction) }\end{array}$ & Removal & $\begin{array}{l}\text { Member of } \\
\text { library } \\
\text { staff }\end{array}$ & $\begin{array}{l}\text { Junk } \\
\text { books- } \\
\text { have no } \\
\text { place in a } \\
\text { college } \\
\text { collection }\end{array}$ & No & No & No & $\begin{array}{l}\text { Request from a former li- } \\
\text { brarian, discussion } \\
\text { with staff }\end{array}$ & $\begin{array}{l}\text { Verbal discussion with complainant; } \\
\text { no further action taken }\end{array}$ \\
\hline 6. Book & Unknown & Unknown & Removal & $\begin{array}{l}\text { Member of } \\
\text { teaching } \\
\text { staff }\end{array}$ & $\begin{array}{l}\text { Viewpoint } \\
\text { outdated }\end{array}$ & No & No & No & Unknown & $\begin{array}{l}\text { Verbal discussion with complainant; } \\
\text { no further action taken }\end{array}$ \\
\hline 7. Book & Unknown & The Act of Love & Removal & $\begin{array}{l}\text { Student, } \\
\text { parent of } \\
\text { student }\end{array}$ & $\begin{array}{l}\text { Sexually ex- } \\
\text { plicit ma- } \\
\text { terial }\end{array}$ & No & No & No & $\begin{array}{l}\text { Verbal discussion with } \\
\text { complainant and li- } \\
\text { brary committee }\end{array}$ & $\begin{array}{l}\text { Verbal discussion with complainant; } \\
\text { material removed temporarily, later } \\
\text { replaced }\end{array}$ \\
\hline 8. Book & Unknown & The Act of Love & Removal & Student & $\begin{array}{l}\text { Sexually ex- } \\
\text { plicit ma- } \\
\text { terial }\end{array}$ & No & No & No & $\begin{array}{l}\text { Verbal discussion with } \\
\text { complainant and li- } \\
\text { brary committee }\end{array}$ & $\begin{array}{l}\text { Verbal discussion with complainant; } \\
\text { material removed temporarily, later } \\
\text { replaced }\end{array}$ \\
\hline & Bell, Clive & $\begin{array}{l}\text { The Intimate } \\
\text { Marriage }\end{array}$ & Removal & $\begin{array}{l}\text { Student, } \\
\text { member } \\
\text { of library } \\
\text { committee }\end{array}$ & $\begin{array}{l}\text { Sexually ex- } \\
\text { plicit ma- } \\
\text { terial }\end{array}$ & No & No & No & $\begin{array}{l}\text { Verbal discussion with } \\
\text { complainant and li- } \\
\text { brary committee }\end{array}$ & $\begin{array}{l}\text { Verbal discussion with complainant; } \\
\text { material removed temporarily, later } \\
\text { replaced }\end{array}$ \\
\hline 10. Book & Horner, Tom & $\begin{array}{l}\text { Jonathan Loved } \\
\text { David: Homo- } \\
\text { sexuality in } \\
\text { Biblical Times }\end{array}$ & Removal & $\begin{array}{l}\text { Member of } \\
\text { teaching } \\
\text { staff }\end{array}$ & $\begin{array}{l}\text { Not in keep- } \\
\text { ing with } \\
\text { institutional } \\
\text { doctrine; } \\
\text { unscholarly } \\
\text { work }\end{array}$ & No & No & No & $\begin{array}{l}\text { Librarian argued with } \\
\text { complainant; decided } \\
\text { it was an improper } \\
\text { choice }\end{array}$ & Material removed \\
\hline
\end{tabular}


APPENDIX A (Continued)

\begin{tabular}{|c|c|c|c|c|c|c|c|c|c|c|}
\hline $\begin{array}{c}\text { Type of } \\
\text { Material }\end{array}$ & Author & Title & $\begin{array}{l}\text { Type of } \\
\text { Request }\end{array}$ & Complainant & $\begin{array}{l}\text { Reason for } \\
\text { Complaint }\end{array}$ & $\begin{array}{c}\text { Written } \\
\text { Selection } \\
\text { Policy }\end{array}$ & $\begin{array}{c}\text { Procedure } \\
\text { for } \\
\text { Complaints }\end{array}$ & $\begin{array}{l}\text { Policy } \\
\text { Used }\end{array}$ & $\begin{array}{l}\text { Method of } \\
\text { Handling } \\
\text { Incident }\end{array}$ & $\begin{array}{l}\text { Final Result } \\
\text { of Complaint }\end{array}$ \\
\hline 11. Book & Twitchell, Paul & $\begin{array}{l}\text { The Far Coun- } \\
\text { try }\end{array}$ & Removal & Student & $\begin{array}{l}\text { Material } \\
\text { harmful } \\
\text { to readers } \\
\text { because it } \\
\text { dealt with } \\
\text { the occult }\end{array}$ & Yes & Yes & Yes & & $\begin{array}{l}\text { Verbal discussion with complainant; } \\
\text { no further action taken }\end{array}$ \\
\hline 12. Films & & $\begin{array}{l}\text { No titles speci- } \\
\text { fied (deal } \\
\text { with issues } \\
\text { in law en- } \\
\text { forcement, } \\
\text { e.g., arson, } \\
\text { fraud, etc.) }\end{array}$ & Relocation & Student & $\begin{array}{l}\text { Sensitive } \\
\text { material- } \\
\text { shouldn't } \\
\text { be avail- } \\
\text { able to } \\
\text { general } \\
\text { public }\end{array}$ & Yes & Yes & No & $\begin{array}{l}\text { Material relocated to ac- } \\
\text { commodate faculty }\end{array}$ & $\begin{array}{l}\text { Material moved to reserve collection } \\
\text { for use by a specific group of stu- } \\
\text { dents }\end{array}$ \\
\hline 13. Book & Benson, Ragnar & $\begin{array}{l}\text { Survival Poach- } \\
\text { ing }\end{array}$ & Relocation & $\begin{array}{l}\text { Member of } \\
\text { teaching } \\
\text { staff }\end{array}$ & $\begin{array}{l}\text { As above; } \\
\text { also con- } \\
\text { cern that } \\
\text { the library } \\
\text { could face } \\
\text { legal } \\
\text { action as a } \\
\text { provider } \\
\text { of infor- } \\
\text { mation }\end{array}$ & Yes & Yes & No & $\begin{array}{l}\text { Material relocated to ac- } \\
\text { commodate faculty }\end{array}$ & $\begin{array}{l}\text { Material moved to reserve collection } \\
\text { for use by a specific group of stu- } \\
\text { dents }\end{array}$ \\
\hline 14. Periodical & & $\begin{array}{l}\text { Sports Illus- } \\
\text { trated (swim- } \\
\text { suit edition } \\
\text { only) }\end{array}$ & Removal & $\begin{array}{c}\text { Member of } \\
\text { teaching } \\
\text { staff }\end{array}$ & $\begin{array}{l}\text { Caters to the } \\
\text { lust of } \\
\text { students } \\
\text { which dis- } \\
\text { tracts } \\
\text { from the } \\
\text { inspirational } \\
\text { and edu- } \\
\text { cational } \\
\text { value of } \\
\text { the maga- } \\
\text { zine }\end{array}$ & 1 & Yes & Yes & & Material removed \\
\hline 15. Book & La Vey, Anton & Satanic Bible & Removal & $\begin{array}{l}\text { Student, } \\
\text { member } \\
\text { of library } \\
\text { staff, ad- } \\
\text { ministrative } \\
\text { official of } \\
\text { the insti- } \\
\text { tution }\end{array}$ & $\begin{array}{l}\text { Serves as } \\
\text { temptation } \\
\text { to explore } \\
\text { the occult } \\
\text { rather } \\
\text { than } \\
\text { serves as } \\
\text { a refer- } \\
\text { ence tool } \\
\text { about Sa- } \\
\text { tanism }\end{array}$ & Yes & Yes & Yes & & Material removed \\
\hline
\end{tabular}


APPENDIX A (Continued)

\begin{tabular}{|c|c|c|c|c|c|c|c|c|c|c|}
\hline $\begin{array}{l}\text { Type of } \\
\text { Material }\end{array}$ & Author & Title & $\begin{array}{l}\text { Type of } \\
\text { Request }\end{array}$ & Complainant & $\begin{array}{l}\text { Reason for } \\
\text { Complaint }\end{array}$ & $\begin{array}{c}\text { Written } \\
\text { Selection } \\
\text { Policy }\end{array}$ & $\begin{array}{c}\text { Procedure } \\
\text { for } \\
\text { Complaints }\end{array}$ & $\begin{array}{l}\text { Policy } \\
\text { Used }\end{array}$ & $\begin{array}{l}\text { Method of } \\
\text { Handling } \\
\text { Incident }\end{array}$ & $\begin{array}{l}\text { Final Result } \\
\text { of Complaint }\end{array}$ \\
\hline 16. Book & $\begin{array}{l}\text { Flumiani, Carlo } \\
\text { Maria }\end{array}$ & $\begin{array}{l}\text { How to Read a } \\
\text { Book for Plea- } \\
\text { sure and } \\
\text { Profit }\end{array}$ & Removal & $\begin{array}{l}\text { Member of } \\
\text { teaching } \\
\text { staff }\end{array}$ & $\begin{array}{l}\text { Book hardly } \\
\text { deals with } \\
\text { topic } \\
\text { suggested- } \\
\text { contains } \\
\text { "way } \\
\text { out" } \\
\text { ideas } \\
\text { about a lot } \\
\text { of unre- } \\
\text { lated } \\
\text { topics- } \\
\text { basically a } \\
\text { "ripoff" }\end{array}$ & . & Yes & Yes & & Material removed \\
\hline 17. Books & & $\begin{array}{l}\text { No titles speci- } \\
\text { fied (books } \\
\text { on the oc- } \\
\text { cult) }\end{array}$ & Removal & $\begin{array}{l}\text { Administrative } \\
\text { official of } \\
\text { the institu- } \\
\text { tion }\end{array}$ & $\begin{array}{l}\text { Possible use } \\
\text { of books } \\
\text { in occult } \\
\text { activities }\end{array}$ & Yes & No & No & $\begin{array}{l}\text { Request discussed by } \\
\text { representatives of li- } \\
\text { brary committee with a } \\
\text { professor of counseling } \\
\text { for his opinion }\end{array}$ & No action taken \\
\hline 18. Periodical & & Wittenberg Door & Removal & Student & $\begin{array}{l}\text { No reason } \\
\text { specified }\end{array}$ & Yes & No & No & $\begin{array}{l}\text { Library committee re- } \\
\text { jected request }\end{array}$ & No action taken \\
\hline 19. Book & Bowes, Mary & Lying in Bed & $\begin{array}{l}\text { Removal } \\
\text { (keep } \\
\text { out of } \\
\text { circula- } \\
\text { tion) }\end{array}$ & $\begin{array}{l}\text { Member of } \\
\text { library } \\
\text { staff }\end{array}$ & $\begin{array}{c}\text { Illustrations } \\
\text { offensive }\end{array}$ & Yes & No & No & $\begin{array}{l}\text { Explained verbally to } \\
\text { complainant that the } \\
\text { book had been ordered } \\
\text { for a particular course } \\
\text { and was needed both } \\
\text { by students and fac- } \\
\text { ulty }\end{array}$ & $\begin{array}{l}\text { Verbal discussion with complainant; } \\
\text { no further action taken }\end{array}$ \\
\hline 20. Periodical & & Soviet Life & $\begin{array}{l}\text { Removal } \\
\text { (request } \\
\text { to stop } \\
\text { buying) }\end{array}$ & $\begin{array}{l}\text { Member of } \\
\text { library } \\
\text { staff }\end{array}$ & $\begin{array}{l}\text { Complainant } \\
\text { "sees red" } \\
\text { when she } \\
\text { sees the } \\
\text { word "So- } \\
\text { viet" }\end{array}$ & Yes & No & No & $\begin{array}{l}\text { Explained to complainant } \\
\text { that material in the li- } \\
\text { brary presents various } \\
\text { points of view }\end{array}$ & $\begin{array}{l}\text { Verbal discussion with complainant; } \\
\text { no further action taken }\end{array}$ \\
\hline 21. Book & Unknown & Unknown & Removal & $\begin{array}{l}\text { Student, } \\
\text { member } \\
\text { of teach- } \\
\text { ing staff, } \\
\text { member } \\
\text { of library } \\
\text { staff, ad- } \\
\text { ministrative } \\
\text { official of } \\
\text { institution }\end{array}$ & $\begin{array}{l}\text { Ours is a } \\
\text { private } \\
\text { church } \\
\text { school } \\
\text { and the } \\
\text { material } \\
\text { in ques- } \\
\text { tion was } \\
\text { not suit- } \\
\text { able for } \\
\text { our school }\end{array}$ & Yes & No & No & $\begin{array}{l}\text { Librarian simply exam- } \\
\text { ined the material and } \\
\text { withdrew it from the } \\
\text { shelves }\end{array}$ & Material removed \\
\hline
\end{tabular}


APPENDIX A (Continued)

\begin{tabular}{|c|c|c|c|c|c|c|c|c|c|c|}
\hline $\begin{array}{l}\text { Type of } \\
\text { Material }\end{array}$ & Author & Title & $\begin{array}{l}\text { Type of } \\
\text { Request }\end{array}$ & Complainant & $\begin{array}{l}\text { Reason for } \\
\text { Complaint }\end{array}$ & $\begin{array}{l}\text { Written } \\
\text { Selection } \\
\text { Policy }\end{array}$ & $\begin{array}{l}\text { Procedure } \\
\text { for } \\
\text { Complaints }\end{array}$ & $\begin{array}{l}\text { Policy } \\
\text { Used }\end{array}$ & $\begin{array}{l}\text { Method of } \\
\text { Handling } \\
\text { Incident }\end{array}$ & $\begin{array}{c}\text { Final Result } \\
\text { of Complaint }\end{array}$ \\
\hline 22. Books & & $\begin{array}{l}\text { No titles speci- } \\
\text { fied (chil- } \\
\text { dren's } \\
\text { books) }\end{array}$ & Removal & Student & $\begin{array}{l}\text { Inaccurate } \\
\text { portrayal } \\
\text { of wom- } \\
\text { en's } \\
\text { skills, } \\
\text { abilities, } \\
\text { and role } \\
\text { in society }\end{array}$ & Yes & No & Yes & $\begin{array}{l}\text { Explanation of collecting } \\
\text { policy of academic li- } \\
\text { brary to provide access } \\
\text { to all types of material } \\
\text { and role of educators } \\
\text { to be aware of such } \\
\text { materials in directing } \\
\text { studies }\end{array}$ & $\begin{array}{l}\text { Verbal discussion with complainant; } \\
\text { no further action taken }\end{array}$ \\
\hline 23. & & & $\begin{array}{l}\text { Reclassi- } \\
\text { fication }\end{array}$ & $\begin{array}{l}\text { Member of } \\
\text { library } \\
\text { staff }\end{array}$ & $\begin{array}{l}\text { Judgmental } \\
\text { bias of tra- } \\
\text { ditional } \\
\text { terms } \\
\text { used in } \\
\text { subject } \\
\text { headings }\end{array}$ & Yes & No & Yes & $\begin{array}{l}\text { Referred to cataloging } \\
\text { policy groups for sub- } \\
\text { sequent guidelines on } \\
\text { internal practice and } \\
\text { communication with } \\
\text { LC regarding practice }\end{array}$ & $\begin{array}{l}\text { Preference given to up-to-date subject } \\
\text { headings as authorized }\end{array}$ \\
\hline 24. Periodical & & $\begin{array}{l}\text { Sports Illus- } \\
\text { trated (swim- } \\
\text { suit edition } \\
\text { only) }\end{array}$ & $\begin{array}{l}\text { Removal// S } \\
\text { relocation } \\
\text { (cut } \\
\text { magazine } \\
\text { up to } \\
\text { remove } \\
\text { pages) }\end{array}$ & $\begin{array}{l}\text { Student, } \\
\text { member } \\
\text { of teach- } \\
\text { ing staff, } \\
\text { member } \\
\text { of library } \\
\text { staff, ad- } \\
\text { ministrative } \\
\text { official of } \\
\text { the insti- } \\
\text { tution }\end{array}$ & $\begin{array}{l}\text { Offensive } \\
\text { material- } \\
\text { provocative } \\
\text { poses and } \\
\text { revealing } \\
\text { non- } \\
\text { clothing }\end{array}$ & Yes & Yes & Yes & & $\begin{array}{l}\text { Pictures cut out, i.e., worst ones (this } \\
\text { is the only case of altering the en- } \\
\text { tity allowed in our policies) }\end{array}$ \\
\hline 25. Periodical & & Wittenberg Door & Removal & $\begin{array}{l}\text { Student, par- } \\
\text { ent, mem- } \\
\text { ber of } \\
\text { teaching } \\
\text { staff, } \\
\text { member of } \\
\text { library, } \\
\text { administra- } \\
\text { tive official } \\
\text { of institu- } \\
\text { tion }\end{array}$ & $\begin{array}{l}\text { Offensive } \\
\text { material- } \\
\text { a Chris- } \\
\text { tian } \\
\text { equivalent } \\
\text { of National } \\
\text { Lampoon- } \\
\text { many } \\
\text { people } \\
\text { find it } \\
\text { hard to } \\
\text { laugh at } \\
\text { themselves }\end{array}$ & Yes & Yes & Yes & & $\begin{array}{l}\text { Verbal discussion with complainant; } \\
\text { no further action taken }\end{array}$ \\
\hline 26. Encyclopedia & & $\begin{array}{l}\text { Encyclopaedia } \\
\text { Britannica } \\
\text { (11th edi- } \\
\text { tion) }\end{array}$ & $\begin{array}{l}\text { Removal/ } \\
\text { relocation }\end{array}$ & $\begin{array}{l}\text { Member of } \\
\text { teaching } \\
\text { staff }\end{array}$ & $\begin{array}{l}\text { Negroes } \\
\text { section is } \\
\text { blatantly } \\
\text { racist }\end{array}$ & Yes & No & Yes & & $\begin{array}{l}\text { Written letter of complaint came to di- } \\
\text { rector; no further action taken }\end{array}$ \\
\hline
\end{tabular}


APPENDIX A (Continued)

\begin{tabular}{|c|c|c|c|c|c|c|c|c|c|c|}
\hline $\begin{array}{l}\text { Type of } \\
\text { Material }\end{array}$ & Author & Title & $\begin{array}{l}\text { Type of } \\
\text { Request }\end{array}$ & Complainant & $\begin{array}{l}\text { Reason for } \\
\text { Complaint }\end{array}$ & $\begin{array}{l}\text { Written } \\
\text { Selection } \\
\text { Policy }\end{array}$ & $\begin{array}{l}\text { Procedure } \\
\text { for } \\
\text { Complaints }\end{array}$ & $\begin{array}{l}\text { Policy } \\
\text { Used }\end{array}$ & $\begin{array}{l}\text { Method of } \\
\text { Handling } \\
\text { Incident }\end{array}$ & $\begin{array}{l}\text { Final Result } \\
\text { of Complaint }\end{array}$ \\
\hline 27. Book & Butz, Arthur R. & $\begin{array}{l}\text { The Hoax of the } \\
\text { Twentieth } \\
\text { Century }\end{array}$ & $\begin{array}{l}\text { Reclassi- } \\
\text { fication }\end{array}$ & 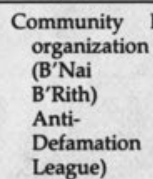 & $\begin{array}{l}\text { Revisionist } \\
\text { material } \\
\text { should } \\
\text { not be } \\
\text { treated as } \\
\text { history }\end{array}$ & Yes & No & Yes & & $\begin{array}{l}\text { Classification unchanged; subject } \\
\text { heading modified }\end{array}$ \\
\hline 28. Book & Butz, Arthur R. & $\begin{array}{l}\text { The Hoax of the } \\
\text { Twentieth } \\
\text { Century }\end{array}$ & Removal & $\begin{array}{l}\text { Law en- } \\
\text { forcement } \\
\text { official }\end{array}$ & $\begin{array}{l}\text { Material } \\
\text { prohibited } \\
\text { under } \\
\text { Customs } \\
\text { Act }\end{array}$ & Yes & No & Yes & & $\begin{array}{l}\text { Material removed initially but recov- } \\
\text { ered on appeal }\end{array}$ \\
\hline 29. Periodical & & Playboy & Removal & $\begin{array}{l}\text { Student, } \\
\text { member } \\
\text { of library } \\
\text { staff }\end{array}$ & $\begin{array}{l}\text { Material is } \\
\text { sexist, un- } \\
\text { academic, } \\
\text { demeaning } \\
\text { to women }\end{array}$ & Yes & No & No & $\begin{array}{l}\text { Incident handled at area } \\
\text { library level }\end{array}$ & Material removed \\
\hline 30. Book & $\begin{array}{l}\text { Trudeau, Mar- } \\
\text { garet }\end{array}$ & $\begin{array}{l}\text { No title speci- } \\
\text { fied (her bi- } \\
\text { ography) }\end{array}$ & $\begin{array}{l}\text { Request } \\
\text { not to } \\
\text { purchase }\end{array}$ & Unknown & $\begin{array}{l}\text { Material is } \\
\text { trash }\end{array}$ & Yes & No & Unknown & $\begin{array}{l}\text { Incident happened upon } \\
\text { by chance by director } \\
\text { of libraries }\end{array}$ & $\begin{array}{l}\text { Area concerned instructed to pur- } \\
\text { chase }\end{array}$ \\
\hline 31. Books & & $\begin{array}{l}\text { No titles speci- } \\
\text { fied (books } \\
\text { on human } \\
\text { reproduction } \\
\text { and sexual } \\
\text { relations) }\end{array}$ & $\begin{array}{l}\text { Removal/ } \\
\text { relocation }\end{array}$ & $\begin{array}{l}\text { Student, } \\
\text { parent, } \\
\text { member } \\
\text { of teach- } \\
\text { ing staff, } \\
\text { member } \\
\text { of library } \\
\text { staff, ad- } \\
\text { ministrative } \\
\text { official of } \\
\text { institution }\end{array}$ & $\begin{array}{l}\text { Offensive } \\
\text { material- } \\
\text { much of } \\
\text { our con- } \\
\text { stituency } \\
\text { and stu- } \\
\text { dents are } \\
\text { very sen- } \\
\text { sitive to } \\
\text { seeing } \\
\text { this mate- } \\
\text { rial in } \\
\text { print and } \\
\text { consider it } \\
\text { pornography }\end{array}$ & 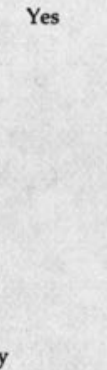 & Yes & Yes & & $\begin{array}{l}\text { Material relocated to special collec- } \\
\text { tions for sexual materials }\end{array}$ \\
\hline 32. Film & & Not a Love Story & $\begin{array}{l}\text { Relocation/ } \\
\text { restricted } \\
\text { access }\end{array}$ & $\begin{array}{l}\text { Member of } \\
\text { teaching } \\
\text { staff }\end{array}$ & $\begin{array}{l}\text { Our students } \\
\text { are not } \\
\text { mature } \\
\text { enough to } \\
\text { see the } \\
\text { film with- } \\
\text { out guided } \\
\text { discussion } \\
\text { afterwards }\end{array}$ & Yes & No & No & $\begin{array}{l}\text { Discussion at librarians' } \\
\text { meeting }\end{array}$ & $\begin{array}{l}\text { Decision to restrict access to users } 18 \\
\text { years and older in conformity with } \\
\text { the film's " } R \text { " rating }\end{array}$ \\
\hline
\end{tabular}


APPENDIX A (Continued)

\begin{tabular}{|c|c|c|c|c|c|c|c|c|c|c|}
\hline $\begin{array}{l}\text { Type of } \\
\text { Material }\end{array}$ & Author & Title & $\begin{array}{l}\text { Type of } \\
\text { Request }\end{array}$ & Complainant & $\begin{array}{l}\text { Reason for } \\
\text { Complaint }\end{array}$ & $\begin{array}{c}\text { Written } \\
\text { Selection } \\
\text { Policy }\end{array}$ & $\begin{array}{l}\text { Procedure } \\
\text { for } \\
\text { Complaints }\end{array}$ & $\begin{array}{l}\text { Policy } \\
\text { Used }\end{array}$ & $\begin{array}{l}\text { Method of } \\
\text { Handling } \\
\text { Incident }\end{array}$ & $\begin{array}{l}\text { Final Result } \\
\text { of Complaint }\end{array}$ \\
\hline 33. Book & Portwood, Doris & $\begin{array}{l}\text { Common Sense } \\
\text { Suicide }\end{array}$ & Removal & Student & $\begin{array}{l}\text { Library } \\
\text { should } \\
\text { not pro- } \\
\text { vide ma- } \\
\text { terial } \\
\text { which } \\
\text { would as- } \\
\text { sist some- } \\
\text { one with } \\
\text { suicidal } \\
\text { tendencies }\end{array}$ & Yes & No & No & $\begin{array}{l}\text { Student left material at } \\
\text { reference desk for li- } \\
\text { brarian to make a deci- } \\
\text { sion }\end{array}$ & $\begin{array}{l}\text { Verbal discussion with complainant; } \\
\text { no further action taken }\end{array}$ \\
\hline 34. Books & & $\begin{array}{l}\text { No titles speci- } \\
\text { fied (popular } \\
\text { religion) }\end{array}$ & Removal & $\begin{array}{l}\text { Member of } \\
\text { teaching } \\
\text { staff }\end{array}$ & $\begin{array}{l}\text { Items are } \\
\text { trash and } \\
\text { not suit- } \\
\text { able to } \\
\text { support } \\
\text { course }\end{array}$ & Yes & No & No & $\begin{array}{l}\text { Librarian pointed out to } \\
\text { complainant that these } \\
\text { books are of use to stu- } \\
\text { dents in psychology } \\
\text { and sociology }\end{array}$ & $\begin{array}{l}\text { Verbal discussion with complainant; } \\
\text { no further action taken }\end{array}$ \\
\hline 35. Videotapes & & $\begin{array}{l}\text { No titles speci- } \\
\text { fied (sex } \\
\text { therapy) }\end{array}$ & $\begin{array}{c}\text { Relocation/ } \\
\text { restricted } \\
\text { access }\end{array}$ & $\begin{array}{l}\text { Member of } \\
\text { teaching } \\
\text { staff, } \\
\text { member } \\
\text { of library } \\
\text { staff }\end{array}$ & $\begin{array}{l}\text { Students } \\
\text { would use } \\
\text { them as } \\
\text { "pornography } \\
\text { shows" } \\
\text { since the } \\
\text { full vari- } \\
\text { ety of sex- } \\
\text { ual activi- } \\
\text { ties were } \\
\text { shown }\end{array}$ & Yes & No & No & $\begin{array}{l}\text { Portions of videos shown } \\
\text { at librarians' meeting, } \\
\text { followed by discussion }\end{array}$ & $\begin{array}{l}\text { Relocate/restrict access to those stu- } \\
\text { dents who have professor's permis- } \\
\text { sion }\end{array}$ \\
\hline 36. Periodical & & Playboy & Removal & $\begin{array}{l}\text { Student, } \\
\text { member } \\
\text { of library } \\
\text { staff }\end{array}$ & $\begin{array}{l}\text { Inappropriate, } \\
\text { not } \\
\text { course- } \\
\text { related, in } \\
\text { tatters } \\
\text { within } \\
\text { two } \\
\text { weeks }\end{array}$ & 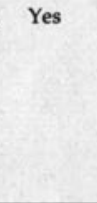 & No & No & $\begin{array}{l}\text { Discussion at librarians' } \\
\text { meeting }\end{array}$ & $\begin{array}{l}\text { Verbal discussion with complainant; } \\
\text { no further action taken }\end{array}$ \\
\hline
\end{tabular}

